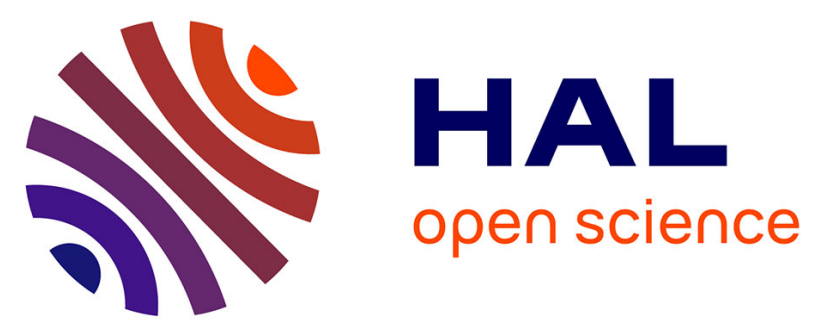

\title{
Borehole water and hydrologic model around the Nojima fault, SW Japan
}

Koichiro Fujimoto, A. Ueda, Tomoyuki Ohtani, M. Takahashi, Hisao Ito, H. Tanaka, Anne-Marie Boullier

\section{- To cite this version:}

Koichiro Fujimoto, A. Ueda, Tomoyuki Ohtani, M. Takahashi, Hisao Ito, et al.. Borehole water and hydrologic model around the Nojima fault, SW Japan. Tectonophysics, 2007, 443, pp.174-182. 10.1016/j.tecto.2007.01.015 . hal-00194305

\section{HAL Id: hal-00194305 https://hal.science/hal-00194305}

Submitted on 6 Dec 2007

HAL is a multi-disciplinary open access archive for the deposit and dissemination of scientific research documents, whether they are published or not. The documents may come from teaching and research institutions in France or abroad, or from public or private research centers.
L'archive ouverte pluridisciplinaire HAL, est destinée au dépôt et à la diffusion de documents scientifiques de niveau recherche, publiés ou non, émanant des établissements d'enseignement et de recherche français ou étrangers, des laboratoires publics ou privés. 


\section{Borehole water and hydrologic model around the Nojima fault, SW Japan}

K. Fujimoto (1), A. Ueda (2), T. Ohtani (3), M.Takahashi (4), H. Ito (4), H. Tanaka (5), Anne-Marie Boullier (6)

(1)Faculty of Education, Tokyo Gakugei University, Tokyo Japan

(2)Central Research Institute, Mitsubishi Materials Corporation, Saitama, Japan

(3)Department of Civil Engineering, Gifu University, Gifu, Japan

(4)GSJ, AIST, Tsukuba, Japan

(5)Department of Earth and Planetary Sciences, University of Tokyo, Tokyo, Japan

(6)LGIT, CNRS, Grenoble, France

koichiro@u-gakugei.ac.jp/ Fax: +81-42-329-7539

Key words: carbonate, stable isotope, water-rock interaction, geochemical speciation 


\begin{abstract}
The active fault drilling at Nojima Hirabayashi after the 1995 Hyogoken-nanbu (Kobe) earthquake $\left(\mathrm{M}_{\mathrm{JMA}}=7.2\right)$ provides us with a unique opportunity to investigate subsurface fault structure and the in-situ properties of fault and fluid. The borehole intersected the fault gouge of the Nojima fault at a depth interval of $623 \mathrm{~m}$ to $625 \mathrm{~m}$. The lithology is mostly Cretaceous granodiorite with some porphyry dikes.

The fault core is highly permeable due to fracturing. The borehole water was sampled in 1996 and 2000 from the depth interval between 630 and $650 \mathrm{~m}$, just below the fault core. The chemical and isotopic compositions were analyzed. Carbon and oxygen isotope ratios of carbonates from the fault core were analyzed to estimate the origin of fluid.

The following conclusions were obtained. (1) The ionic and isotopic compositions of borehole water did not change from 1996 to 2000. They are mostly derived from local ground water as mentioned by Sato and Takahashi (2000). (2) Geochemical speciation revealed that the borehole water was derived from a relatively deep reservoir, which may be situated at a depth of 3 to $4 \mathrm{~km}$ where the temperature is about $80-90{ }^{\circ} \mathrm{C}$. (3) The shallower part of the Nojima fault (shallower than the reservoir depth) has not been healed from the hydrological viewpoints 5 years after the event, in contrast to the rapid healing detected by S wave splitting (Tadokoro and Ando, 2002). (4) Precipitation of calcite from present borehole water since drilling supports the idea of precipitation of some calcite in coseismic hydraulic fractures in the fault core (Boullier et al., 2004). (5) Carbon and oxygen isotope ratios of calcite indicated that the meteoric water flux had been localized at the fault core. (6) A difference in the carbon isotope ratio between the footwall and the hangingwall suggests that the fault has been acted as a hydrologic barrier, although the permeability along the fault is still high.
\end{abstract}

\title{
1. Introduction
}

A fault zone provides a pathway for fluid, which plays an important role in fault processes including long-term evolution of fault structure, fault creep, nucleation-propagation-arrest and recurrence of earthquake ruptures (Hickman et al., 1995). Geological Survey of Japan (GSJ) drilled a borehole at Nojima Hirabayashi just after 1995 Hyogoken-nanbu (Kobe) earthquake, succeeded in penetrating the fault core and recovered complete sequences of the fault rocks from the protolith to the fault core. The drilling of active fault is advantageous for integrated study of geological data and hydrological data and comparison to exhumed faults.

We conducted a series of studies on the fault rocks from the GSJ borehole and clarified the detailed fault zone architecture (Ohtani et al., 2001; Tanaka et al., 2001), the assemblages and occurrences of alteration minerals (Fujimoto et al., 2001), and 
characteristics of paleo-fault-related fluid based on fluid inclusions (Ohtani et al., 2000 Boullier et al., 2001). These studies suggest intensive deformation and alteration is localized within a narrow fault core with thickness of about $30 \mathrm{~cm}$, whereas the damaged zone extends more than a few tens of meters similar to the Punchbowl and San Gabriel faults, exhumed faults of the San Andreas system (Chester et al., 1993).

As for hydrological studies, pumping tests were performed in 1996 and 2000 to examine the permeability recovery after the event. The fault zone has higher permeability than the intact host rock (Roeloffs et al., 2000 and 2004) and the chemistry of the borehole water indicate that the waters are carbonate rich and mostly of meteoric origin (Sato and Takahashi, 1997 and 2000). Recently, Boullier et al. (2004) examined the occurrences and texture of carbonate minerals and concluded that some carbonate minerals were precipitated in very recent coseismic hydraulic fractures.

In this paper we summarize the characteristics of the borehole water and precipitated materials, and discuss the alteration and carbonate isotopes of carbonate. We will combine these informations with previous work to construct hydrologic model for the Nojima fault.

\section{Outline of the fault and core geology}

The Nojima fault is a NE-SW striking active right-lateral strike-slip fault with a minor reverse component (Mizuno et al., 1990). The drilling site is situated at Nojima Hirabayashi, on the northwestern coast of the Awaji Island, southwest Japan, where the surface displacement of the 1995 event was a maximum of 2.5m (Awata et al., 1996) (Fig.1). The drilling site is $74.6 \mathrm{~m}$ east of the surface rupture and reached a depth of $746.7 \mathrm{~m}$ with a maximum of 5 degrees deviation from the vertical as shown in Fig. 1. The geology and tectonic setting of this region is described in Murata et al. (2001).

The borehole intersected the fault gouge of the Nojima fault at about $624 \mathrm{~m}$ depth. We identified the fault core at the depth interval between 623.1 and $625.3 \mathrm{~m}$ because the thickest section of fault gouge in the borehole is in a steeply dipping zone that aligns with the surface trace. Furthermore, the results of geophysical logging (Ito et al., 1996) show various anomalies at this depth such as a sudden decrease in P-wave velocity. Temperature logging data show that the present temperature at the bottom of the hole is about $31^{\circ} \mathrm{C}$ (Ito, unpublished data).

The internal structure of the Nojima fault was described in detail in Ohtani et al. (2000) and Tanaka et al. (2001) and we provide a brief summary here. The lithology is mostly Cretaceous granodiorite with some porphyry dikes. The rocks above $426 \mathrm{~m}$ depth are nearly intact granodiorite. The borehole enters the fault zone at $426 \mathrm{~m}$ depth and the rocks are affected by the fault through the bottom of the borehole. Characteristic alteration minerals in the fault zone are smectite, zeolites (laumontite, stilbite) and 
carbonate minerals (calcite, siderite, and dolomite) as shown in Fig. 2. The mineral assemblages and texture indicate several episodes of hydrothermal activity in the fault zone. Chlorite, which is distributed throughout the entire depth, is probably a relic of deuteric alteration. Carbonate minerals are important as sealing material in the shallower level of the Nojima fault (Fujimoto et al., 2001; Boullier et al., 2004). Intense alteration is localized in the narrow zone of fault gouge and fault breccias.

Boullier et al. (2001) described pseudotachylyte bands in the fault core and estimated the formation condition to be $200^{\circ} \mathrm{C}$ and deeper than $10 \mathrm{~km}$. Murakami and Tagami (2004) conducted zircon fission track dating of the pseudotachylyte and estimated the cooling time to be 30 to $40 \mathrm{Ma}$. These facts suggest that the recovered samples of the core of the Nojima fault experienced long and complicated history.

\section{Borehole water chemistry}

\subsection{Experimental}

The borehole was completed with a casing that is perforated in the 630 and $650 \mathrm{~m}$ depth interval, just below the fault core. Borehole water was sampled during the pumping tests performed in April, 1996 (about one year after the event) and in February, 2000 (about five years after the event). The chemistry of the borehole water obtained in 1996 were analyzed by Sato and Takahashi (2000) and discussed in Boullier et al. (2004). Chemistry of 2000 water is provided here (Table 1 and 2).

The pumping rate was $50 \mathrm{l} / \mathrm{min}$. The electric conductivity and $\mathrm{pH}$ were measured on-site with electrodes after sampling. The borehole water was immediately filtered through a $0.45 \mu \mathrm{m}$ membrane, acidified, and stored in plastic bottles for subsequent chemical and isotopic analysis. The analysis was conducted by Mitsubishi Materials. Total iron and $\mathrm{Fe}^{3+}$ were analyzed using spectrophotometric techniques. The samples were pretreated by addition of aliquots of 1,10-phenanthroline, $\mathrm{HCl}$ and ammonium acetate solutions for $\mathrm{Fe}^{3+}$ determinations. For total iron determinations, $\mathrm{HCl}$, hydrochloric hydroxylamine solution, 1,10-phenanthroline and ammonium acetate solution were added to water samples. Ferrous iron was calculated from the difference between total iron and $\mathrm{Fe}^{3+}$.

A titration method was used for carbonate species determinations. Anions were measured by ion chromatography and cations were determined by ICP-AES. Analytical uncertainties are typically about 5 to $10 \%$ for trace components and better than $5 \%$ for major components.

\subsection{Ionic and isotopic compositions}


The chemical compositions of the borehole waters are shown in Table 1 (data for the 1996 sample is after Sato and Takahashi, 1997, 2000). The major cation and anion components are calcium and bicarbonate ions, respectively. The ionic characteristics are similar to those of local spring water in the northern part of the Awaji Island (Sato and Takahashi, 2000). The water chemistry of the 1996 and 2000 samples is essentially the same.

The isotopic compositions of the 1996 water were examined by Sato and Takahashi (2000). They concluded that the water was derived from local ground water because the hydrogen and oxygen isotope ratios are the same trend as that of local ground water and the helium isotopic ratio is the same as that of the atmosphere. The isotopic composition of the 2000 water is similar to the 1996 water (Table 2).

\subsection{The geochemical speciation}

We ran a geochemical speciation code on the borehole water samples and calculated the saturation index (SI) of several minerals at the temperature range between 25 and $100{ }^{\circ} \mathrm{C}$ using WEB-PHREEQ, a WWW implementation of the aqueous geochemical modeling program PHREEQC (http://www.ndsu.nodak.edu/webphreeq/). Details of the code are given in Parkhurst and Appelo (1999). Figure 3 shows changes in the saturation index (SI) of carbonates (calcite, siderite and dolomite), quartz, Ca-montmorillonite and illite with at $25^{\circ} \mathrm{C}$ as for the 1996 water and 2000 water respectively. Gibbsite and goethite are assumed to be an equilibrium phase. As Boullier et al. (2004) mentioned, the 1996 water is saturated with respect to calcite, siderite, dolomite, quartz, illite and Ca-montmorillonite at $25^{\circ} \mathrm{C}$. This is concordant with the assemblages of alteration minerals in the fault gouge zone (Fujimoto et al., 2001). The SI values of calcite, siderite and dolomite are positive, whereas, those of quartz, Ca-montmorillonite and illite decrease with temperature. They change from positive to negative at about $90^{\circ} \mathrm{C}$. The changes in SI values can be used as a geothermometer (Reed and Spycher, 1984). It suggests that the water comes from a reservoir at about 90 ${ }^{\circ} \mathrm{C}$ and in equilibrium with those minerals. If the present geothermal gradient in this region is about $24^{\circ} \mathrm{C} / \mathrm{km}$ (Kitajima et al., 1998), the depth of the reservoir might be $4 \mathrm{~km}$. The calculation results are quite similar to those for the 2000 water except siderite is always undersaturated.

\section{Precipitates from the borehole water}

Small amounts of solid materials were found on the borehole seismometer, that was settled near the bottom of the hole during March 2003 to March 2004. The materials were brownish in color, and calcite, goethite and opaline silica were identified by the 
X-ray powder diffraction patterns. A SEM image (Fig. 4) shows that calcite exhibits rectangular crystals of about a few tens of micrometers in length. The siliceous materials (opaline silica) and iron oxide or hydroxide (goethite?) are considered to be in equilibrium with the borehole water and geochemical speciation mentioned above. Therefore, we think the materials were precipitated in-situ from the borehole water.

Boullier et al. (2004) found euhedral carbonate crystals ( $5-50 \mu \mathrm{m}$ in size) in the fault core and hangingwall. They concluded that they were precipitated in recent seismic stages. Our findings support their conclusions.

\section{Carbon and oxygen isotope ratios of carbonates in fault rocks}

The samples from the GSJ borehole includes carbonate minerals (calcite, siderite and dolomite) as veins or partial replacement of primary mafic minerals through the whole core (Fujimoto et al., 2001). They are also major matrix cements in the fault core (Boullier et al., 2004). Their carbon and oxygen isotope ratios are expected to record the precipitation environment and origin of the fluid.

Ueda et al., (2000) analyzed 36 carbonate containing rock samples from the various depth covering fault zone and intact part. The carbonate isotope is characterized by high

$\delta^{18} \mathrm{O}(\mathrm{SMOW})$ values which may result from the influence of sea water carbon (Ueda et al., 2000). Sea water has not been recognized in groundwaters and the surrounding hot springs around the Nojima fault, thus, the possibility of connate sea waters should be considered. This is confirmed by Arai et al., (2003) using the NIED core, which penetrates the Nojima fault at deeper depth than GSJ borehole.

We analyzed three additional samples of fault gouge from 623 to $625 \mathrm{~m}$ depth. The collected samples were powdered, and about $100 \mathrm{mg}$ aliquot of powder were reacted with phosphoric acid in vacuum at $25^{\circ} \mathrm{C}$ for one day (McCrea, 1950) and the $\mathrm{CO}_{2}$ gas extracted was analyzed for the isotopic compositions by a Finnigan Mat Delta-E mass spectrometer. The uncertainties are within $\pm 0.2 \%$ for both carbon and oxygen isotopes. The analysis was conducted by Mitsubishi Materials. The changes in both carbon and oxygen isotope ratios with depth are shown in Fig. 5.

Carbonates in the fault core $\left(623 \sim 625 \mathrm{~m}\right.$ depth) are characterized by low $\delta^{18} \mathrm{O}$ (about $15 \%$ o and relatively high $\delta^{13} \mathrm{C}(-3.5 \sim-1.9 \%$ o values compared to the fault rocks analyzed by Ueda et al. (2000). We re-examined the previous data by Ueda et al. (2000) and found the hangingwall and footwall are different in both carbon and oxygen isotope ratios. The isotopic variation of carbonate among intact part, hangingwall, and footwall will be discussed later.

Carbonates in the intact zone (above $426 \mathrm{~m}$ depth) are characterized by low $\delta^{13} \mathrm{C}(<$ $-5.8 \%$ ). Carbonates in the hangingwall (426 623m depth) and footwall (625 746m depth) are different in $\delta^{13} \mathrm{C}$ values, but $\delta^{18} \mathrm{O}$ values are nearly in the same range. $\delta^{13} \mathrm{C}$ 
value is -1.3 to $-6.0 \%$ in the hangingwall and it is -0.5 to $-2.4 \%$ in the footwall. This difference results from differences in the original fluid and/or precipitation environment.

\section{Discussion}

\subsection{Implications for fault healing after 1995 event}

Understanding fault healing process is one of the biggest goals for fault drilling after a large seismic event. As for the Nojima fault, various explorations including electric conductivity survey, seismic survey, pumping test and injection test, have been conducted repeatedly (e.g., Ando, 2001).

Fault healing means recovery of strength in a strict sense, however, this is difficult to measure. On the other hand, fault healing may be achieved mostly by chemical processes such as dissolution and precipitation of mineral species in the fault zone. Water is necessary for these processes. Thus, changes in hydrological characteristic such as permeability are very important.

The vertical hydraulic diffusivity was estimated to be $0.5 \mathrm{~m}^{2} / \mathrm{s}$ in 1996 (Roeloffs and Matsumoto, 2000) and did not change in order of magnitude in 2000 (Roeloffs and Matsumoto, 2004). Seeing that the ionic and stable-isotope characteristics of 2000 borehole water are similar to 1996 borehole water, the reservoir and fluid path might not change between 1996 April to 2000 February. This suggests that the fault has not been healed from a hydrological viewpoint.

Tadokoro and Ando (2002) suggested that the Nojima fault was healed in 33 months after the 1995 event based on the S wave splitting. We do not think this is paradoxical. Hydraulic conductivity obtained by borehole tests reflects the shallow part of the fault. Considering that reservoir temperature is about $90^{\circ} \mathrm{C}$ and there is no signature of deep component, it would take a lot of time to adhere the fractured fault plane in this shallow part due to the low reaction rates.

In contrast, the reaction rate would be accelerated by higher temperature and pressures in the deeper portion of the fault.

\subsection{Localized meteoric water flux at the fault core}

The carbonates from GSJ borehole are characterized by high $\delta^{18} \mathrm{O}$ relative to calcite from hydrothermal fields in the world (Ueda et al., 2000). Oxygen isotope ratio of carbonate is mainly affected by the nature of source fluid and the temperature of precipitation, to a first approximation. As for the source fluid, sea water (0\%) and local meteoric water (-7.5\%o; after Sato and Takahashi, 2000) are possible end members since there is no signature of mantle or lower crust in the fluids around the Nojima fault. The 
temperature dependence of oxygen isotope value of calcite which is in equilibrium with sea water and local meteoric water can be calculated as follows. $\alpha$ means fractionation factor between two species.

$$
\begin{gathered}
\alpha_{\mathrm{CaCO} 3-\mathrm{H} 2 \mathrm{O}}=\left({ }^{18} \mathrm{O} /{ }^{16} \mathrm{O}\right){ }_{\mathrm{CaCO} 3} /\left({ }^{18} \mathrm{O} /{ }^{16} \mathrm{O}\right){ }_{\mathrm{H} 2 \mathrm{O}} \\
1000 \ln \alpha_{\mathrm{CaCO} 3-\mathrm{H} 2 \mathrm{O}}=\delta^{18} \mathrm{O}\left(\mathrm{CaCO}_{3}\right)-\delta^{18} \mathrm{O}\left(\mathrm{H}_{2} \mathrm{O}\right)=2.78\left(10^{6} / \mathrm{T}^{2}\right)-2.89 \\
\left(\mathrm{~T}<500{ }^{\circ} \mathrm{C}\right. \text {, O'Neil et al., 1969) }
\end{gathered}
$$

The results are shown in Fig.6. The calculation implies two possibilities of the origin of the fluid. One is that connate sea water precipitates carbonates at relatively higher temperatures $\left(100 \sim 200^{\circ} \mathrm{C}\right)$ and the other is that meteoric water precipitates them at relatively lower temperature $\left(<50^{\circ} \mathrm{C}\right)$.

We think the second possibility is preferable because of the following two reasons. (1) Water from the fault core is basically meteoric origin. (2) Ca-bearing mineral species is laumontite under higher temperature environment (higher than about $120^{\circ} \mathrm{C}$ ), instead of calcite (Fujimoto et al., 2001). Thus, localized meteoric water flow at the fault core.

As Ohtani et al. (2000) and Boullier et al. (2004) described, there are several stages of carbonate precipitation. The carbon isotope values mentioned above represent all stages and the difference in each stage should be further checked using a micro-scale analysis technique.

\subsection{Hydrologic model around the Nojima fault}

The carbonates of the hangingwall and footwall have different isotopic characteristics. There are several explanations for this. One simple interpretation is that the isotopes reflect a difference in precipitation temperature. Zeolite species indicate that the hangingwall side has a higher temperature signature than the footwall side due to the reverse component of the Nojima fault (Fujimoto et al., 2001). If the fluid has the same carbon isotope value, carbonate in the footwall side would have lower carbon isotope ratio than that of hangingwall side based on the temperature dependence of the isotope fractionation. As previously mentioned, the carbonate isotope value in the hangingwall side is actually lower than that of footwall side. However, the temperature difference might be less than a few tens of degrees based on the displacement estimation by Murata et al. (2001) and a current geothermal gradient obtained by Kitajima et al. (1998). The difference in carbon isotope ratios cannot be explained by the temperature difference alone. Another possible interpretation is that the fluids in the hangingwall side and in the footwall side originally had different carbon isotope ratios, and that the Nojima fault acted as a hydrologic barrier across the fault.

Lockner et al. (2000) measured strength and matrix permeability of the core samples at $50 \mathrm{MPa}$ confining pressure. The obtained permeability ranges are as follows; 0.1 to 1 microdarcy in the fault core, about 100 microdarcy in the damage zone, and less than sub nanodarcy for the intact rock. They inferred that the post-seismic fault zone acts as a 
high permeability fluid conduit for fluid flow in the plane of the fault because the fault core is likely to act as a barrier across the fault. Their results are in good agreement with the scheme proposed by Caine et al. (1996), though they did not concerned the effect of fracture permeability. The scheme (Caine et al., 1996) is based on the fault architecture, which was characterized by widths of a damage zone and a fault core relative to the width of a total fault zone. Each zone is a distinct structural and hydrogeologic unit. The Nojima fault is categorized into the combined conduit-barrier system because it has both a localized fault core and a wide damage zone.

In the combined conduit-barrier system, the fault core may usually act as a barrier and may act as a conduit during deformation until fractures or pore spaces are filled with minerals. In contrast, the damage zone always acts as conduit (Caine et al., 1996). The carbon and oxygen isotope data presented in this paper support this scheme and the permeability structure proposed by Locker et al. (2000).

Geochemical/mineralogical studies on the samples from the fault core indicate that the fault core mainly composed of hydrous and carbonate minerals and volatile contents are much higher than those of the damage zone (Fujimoto, et al., 2001). Probably, the fault core acts as a conduit only a short interval after a seismic event, considering the minerals can be precipitated quickly (Boullier et al., 2004) and the recurrence time of the Nojima fault is order of thousand years (Awata and Suzuki, 1996). The high vertical hydraulic diffusivity obtained by pumping tests (Roeloffs and Matsumoto, 2000, 2004) reflects the high permeability of the damage zone.

\subsection{Comparison with the other fault drillings}

Recently, several boreholes have been drilled to intersect active faults such as Chelungpu fault, Taiwan, San Andreas fault, USA, and Aigion fault, Corinth, Greece.

Geologic settings of the above faults are completely different. Chelungpu fault, activated in 1999 Chichi earthquake, is one of major thrust faults in sedimentary sequences extending for over $100 \mathrm{~km}$ on the western flank of the Taiwan fold-andthrust belt. San Andreas Fault is a transform fault between Pacific and North American plates. Aigion fault is a normal fault in limestone layers, which extends in the southern part of the Corinth basin.

Detailed comparison is beyond the focus of this paper, however, carbonate minerals seem to be dominant as fractures or cavities filling in the fault zones (Chelungpu fault; Hashimoto et al., 2005, San Andreas fault; Evans et al., 2005, Aigion fault; Labaume et al., 2004) as in the Nojima fault zone. Abundance of carbonate minerals in the shallow part of the fault zone is probably due to up-flow of carbonate rich fluid through a conduit in the fault zones. Kharaka et al. (1999) found relatively high flux of $\mathrm{CO}_{2}$ of mantle origin associated with the San Andreas fault system. Roll of carbonate minerals and carbon bearing fluids in fault processes should be paid more attention. 
Borehole test and geophysical exploration can provide a snap shot image or physical state of the fault zone. On the contrary, geological and geochemical analysis of core samples can indicate the history which the fault zone has experienced. Their integrations are necessary to understand an overall seismic cycle, which is one of the main targets of the drilling of active faults.

\section{Conclusions}

(1) Ionic and isotopic compositions of borehole water did not change from 1996 to 2000 and borehole water is mostly derived from local ground water as Sato and Takahashi (2000) mentioned.

(2) Geochemical speciation suggests that the borehole water was derived from a relatively deep reservoir, which may be situated at the depth of $4 \mathrm{~km}$ and a temperature of about $90^{\circ} \mathrm{C}$.

(3) The shallower part of the Nojima fault (shallower than the reservoir depth) has not been healed from the hydrological viewpoint five years after the large seismic event, in contrast to the rapid healing detected by $\mathrm{S}$ wave splitting (Tadokoro and Ando, 2002).

(4) Precipitation of calcite from present borehole water supports the idea of postseismic precipitation of some portion of calcite in the fault core (Boullier et al., 2004).

(5) Carbon and oxygen isotope ratios of calcite indicate the meteoric water flux has been localized to the fault core.

(6) The difference in carbon isotope ratio between the footwall andhangingwall suggests that the fault has acted as a hydrologic barrier, though the permeability along the fault is still high.

\section{Acknowledgements}

This work was supported by Geological Survey of Japan. The authors thank to Dr. Tsutomu Sato and Dr. Norio Matsumoto of Geological Survey of Japan for providing important information. The suggestions from the reviewers are helpful for improvement of the manuscript.

\section{References}

Ando, M. 2001. Geological and geophysical studies of the Nojima fault from drilling: An outline of the Nojima fault probe. The Island Arc, 10, 206-214.

Arai, T., Tsukahara, H., Morikiyo,T., 2003. Sealing processes with calcite in the Nojima active fault zone revealed from isotope analysis of calcite. Journal of Geography, 112, 915-925 (in Japanese with English abstract) 
Awata, Y. , Mizuno, K. Sugiyama, Y., 1996. Surface fault ruptures on the northwest coast of Awaji Island associated with the Hyogo-ken Nanbu earthquake of 1995, Japan. Zisin II, 49, 134-124 (in Japanese with English abstract).

Awata, Y., Suzuki, Y., 1996. Paleoseismology and activity study of the Nojima fault system, which generated the Hyogo-ken Nanbu earthquake of January 17, 1995. Geological Survey of Japan, Open File Report, 250, 4-8 (in Japanese).

Boullier, A. M., Ohtani, T., Fujimoto, K., Ito, H., Dubois, M., 2001. Fluid inclusions in pseudotachylytes from the Nojima fault, Japan. Journal of Geophysical Research, 106(B10), 21965-21977.

Boullier, A-M., Fujimoto, K., Ohtani, T., Roman-Ross, G., Lewin, E., Ito, H., Pezard, P., Ildefonse, B., 2004. Textural evidence for recent co-seismic circulation of fluids in the Nojima fault zone, Awaji island, Japan., Tectonophysics, 378, 165-181.

Caine, J. S., Evans, J. P. and Forster, G. B., 1996, Fault zone architecture and permeability structure. Geology, 24, 1025-1028.

Chester, F. M., Evans, J. P., Biegel, R .L., 1993. Internal structure and weakening mechanisms of the San Andreas fault. Journal of Geophysical Research, 98, 771-786.

Evans, J. P., Moore, D. E., Kirschner, D. and Solum, J. G., 2005. Lithologic characterization of the deep portion of the SAFOD drillhole. EOS Trans. AGU, 86(52), fall meet. Suppl., Abst. T21A-0450.

Fujimoto, K., Tanaka, H., Higuchi, T., Tomida, N., Ohtani, T., Ito, H., 2001. Alteration and mass transfer inferred from the Hirabayashi GSJ drill core penetrating the Nojima Fault, Japan. The Island Arc, 10, 401-410.

Hashimoto, Y., Nakaya, T., Song, S. R., 2005. Distribution of deformation features and clay mineral characteristics around the Chelungpu fault, Taiwan, EOS Trans. AGU, 86(52), fall meet. Suppl., Abst. T51A-1311.

Hickman, S., Sibson, R. H, Bruhn, R., 1995. Introduction to special section: Mechanical involvement of fluids in faulting. Journal of Geophysical Research, 100(B7), 12831-12840.

Ito, H., Kuwahara, Y., Miyazaki, Y., Nishizawa, O., Kiguchi, T., Fujimoto, K., Ohtani, T., Tanaka, H., Higuchi, T., Agar, S., Brie, A., Yamamoto, H., 1996. Structure and physical properties of the Nojima Fault. BUTSURI-TANSA (Geophysical Exploration), 49, 522-535 (in Japanese with English abstract).

Kharaka, Y., Thordsen, J. J., Evans, W., 1999. Geochemistry and hydromechanical interactions of fluids associated with the San Andreas fault system, California. Geophysical Monograph Series, 113, AGU, 129-148.

Kitajima, T., Kobayashi, Y., Ikeda, R., Iio, Y., Omura, K., 1998. Terrestrial heat flow in Nojima-Hirabayashi, Awaji Island. Chikyu Monthly, 21, 108-113 (in Japanese).

Labaume, P., Carrio-Schaffhauser, E., Gammond, J-F., and Renard, F., 2004. Deformation mechanisms and fluid driven mass transfer in the recent fault zones of the Corinth Rift (Greece). Comptes Rendus Geosciences, 336, 375-383. 
Lockner, D., H. Naka, H. Tanaka, H. Ito and R. Ikeda. 2000. Permeability and strength of core samples from the Nojima fault of the 1995 Kobe earthquake. In: Proceedings of the International Workshop on the Nojima Fault Core and Borehole Data Analysis, Tsukuba, Japan, Nov 22-23, 1999, pp. 147-152, eds. H. Ito, H. Fujimoto, H. Tanaka, and D. Lockner, Open File Report 00-129. U. S. Geological Survey, Menlo Park, CA.

MaCrea, J. M., 1950. On the isotopic chemistry of carbonates and a paleotemperature scale. Jour. Chem. Phys., 18, 849-857.

Mizuno, K., Hattori, H., Sangawa, A., Takahashi, Y., 1990. Geology of the Akashi district with geological sheet map of 1:50000, p.90. Geological Survey of Japan, Ibaraki (in Japanese with English abstract).

Murakami M., Tagami, T., 2004. Dating pseudotachylyte of the Nojima fault using the zircon fission-track method. Geophys. Res. Lett., 31, L12604, doi:10.1029/2004GL020211.

Murata, A., Takemura, K., Miyata, T., Lin, A, 2001. Quaternary vertical offset and average slip rate of the Nojima fault on Awaji island, Japan. The Island Arc, 10, 360-367.

O'Neil, J. R., Clayton, R. N., Mayeda, T. K., 1969. Oxygen isotope fractionation in divalent metal carbonates. Journal of Chemical Physics, 51, 5547-5558.

Ohtani, T., Fujimoto, K., Ito, H., Tanaka, H., Tomida, N., Higuchi, T., 2000. Fault rocks and past to recent fluid characteristics from the borehole survey of the Nojima fault ruptured in the 1995 Kobe earthquake, southwest Japan. Journal of Geophysical Research, 105(B7), 16161-16171.

Ohtani, T., Tanaka, H., Fujimoto, K., Higuchi, T., Tomida, N., Ito, H., 2001. Internal structure of the Nojima Fault Zone from the Hirabayashi GSJ drill core. The Island Arc, 10, 392-400.

Parkhurst, D.L. , Appelo, C. A. J., 1999. PHREEQC (Version 2), A computer program for speciation, batch-reaction, one-dimensional transport and Inverse geochemical calculations. Water-Resources Investigations Report 99-4259, U.S. Geological Survey, Denver, Colorado.

Reed, M., Spycher, N., 1984. Calculation of $\mathrm{pH}$ and mineral equilibria in hydrothermal waters with application to geothermometry and studies of boiling and dilution. Geochim. Cosmochim. Acta, 48, 1479-1492.

Roeloffs, E. A., Matsumoto, N., 2000. Hydrologic properties at the GSJ Hirabayashi borehole in the Nojima fault from analysis of pump test and time series data. GSJ Interim Report No. EQ/00/1, 173-178.

Roeloffs, E. A., Matsumoto, N., Ito, H., 2004, Hydrologic properties and fluid pressure response to strain in the recently ruptured Nojima fault, Japan, submitted to Pure and Applied Geophysics.

Sato, T., Takahashi, M.1997. Geochemical changes in anomalously discharged 
groundwater in Awaji Island after the 1995 Kobe earthquake. Chikyukagaku 31, 89-98 (in Japanese with English abstract).

Sato, T., Takahashi, M., 2000. Chemical and isotopic compositions of groundwater obtained from the Hirabayashi well. GSJ Interim Report No. EQ/00/1, 187-192.

Tadokoro, K., Ando,M., 2002. Evidence for rapid fault healing derived from temporal changes in S wave splitting, Geophys. Res. Lett., 29, 10.1029/2001GL013644.

Tanaka, H., Fujimoto, K., Ohtani, T., Ito, H., 2001. Structural and chemical characterization of shear zones in the freshly activated Nojima fault, Awaji Island, southwest Japan. Journal of Geophysical Research, 106(B5), 8789-8810.

Ueda, A., Kawabata, A., Fujimoto, K., Tanaka, H., Tomida, N., Ohtani, T., Ito, H., 2000. Isotopic study of the Nojima fault cores. GSJ Interim Report No. EQ/00/1, 127-132. 


\section{Figure captions}

Fig.1 Geologic map and fault trace (modified from Ohtani et al., 2000)

Fig.2 Distribution of alteration minerals (modified from Fujimoto et al., 2001).

Fig.3 Changes of saturation index values (S.I.) of several minerals with temperature.

Fig.4 Secondary electron image of precipitates from the borehole water. Calcite appears in the center and surrounding fine materials are goethite. A scale bar is shown in the photograph.

Fig.5 Changes of carbon and oxygen isotope ratios with depth.

Fig.6 Oxygen isotope of calcite in equilibrium with seawater and local meteoric water with temperature. Fractionation factor was based on O’Neil et al. (1969). 


\begin{tabular}{|l|c|c|}
\hline & $1996 \mathrm{Apr}$ & $2000 \mathrm{Feb}$ \\
\hline $\mathrm{pH}$ & 7.8 & 7.57 \\
\hline $\mathrm{Na}^{+}(\mathrm{mg} / \mathrm{L})$ & 36.2 & 32.3 \\
\hline $\mathrm{K}^{+}(\mathrm{mg} / \mathrm{L})$ & 4.7 & 6.92 \\
\hline $\mathrm{Ca}^{2+}(\mathrm{mg} / \mathrm{L})$ & 56.2 & 59.9 \\
\hline $\mathrm{Mg}^{2+}(\mathrm{mg} / \mathrm{L})$ & 20 & 23.8 \\
\hline $\mathrm{Fe}^{2+}(\mathrm{mg} / \mathrm{L})$ & 1 & $<0.1$ \\
\hline $\mathrm{Fe}^{3+}(\mathrm{mg} / \mathrm{L})$ & 0.94 & 0.1 \\
\hline $\mathrm{Mn}^{2+}(\mathrm{mg} / \mathrm{L})$ & 0.16 & 0.07 \\
\hline $\mathrm{Cl}^{-}(\mathrm{mg} / \mathrm{L})$ & 20.4 & 16 \\
\hline $\mathrm{SO}_{4}{ }^{2-}(\mathrm{mg} / \mathrm{L})$ & 5.1 & 9.6 \\
\hline $\mathrm{NO}_{3}{ }^{-}(\mathrm{mg} / \mathrm{L})$ & $<0.05$ & $<0.1$ \\
\hline $\mathrm{F}^{-}(\mathrm{mg} / \mathrm{L})$ & 0.7 & 0.5 \\
\hline $\mathrm{HS}^{-}(\mathrm{mg} / \mathrm{L})$ & $<0.001$ & $<1$ \\
\hline $\mathrm{CO}_{3}{ }^{2-}(\mathrm{mg} / \mathrm{L})$ & $<5$ & $<1$ \\
\hline $\mathrm{HCO}_{3}{ }^{-}(\mathrm{mg} / \mathrm{L})$ & 330 & 390 \\
\hline $\mathrm{H}_{2} \mathrm{SiO}_{3}(\mathrm{mg} / \mathrm{L})$ & 57.2 & 84 \\
\hline
\end{tabular}

Table 1 Chemical composition of GSJ borehole water sample in 1996 April and 2000 February. Data of the 1996 borehole water is after Sato and Takahashi (1997). 


\begin{tabular}{|c|c|c|}
\hline & 1996 Apr & 2000 Feb \\
\hline${ }^{3} \mathrm{H}(\mathrm{TR})$ & $<1$ & 0.89 \\
\hline$\delta \mathrm{D}$ \%oo $)$ & -50 & -50.7 \\
\hline$\delta^{18} \mathrm{O} \%$ oo $)$ & -7.9 & -8.8 \\
\hline$\delta{ }^{13} \mathrm{C} \quad \begin{array}{c}\text { dissoluved carbon) } \\
\text { qoo })\end{array}$ & -12 & -9.6 \\
\hline${ }^{87} \mathrm{Sr} /{ }^{86} \mathrm{Sr}$ & $\mathrm{NA}$ & 0.708479 \\
\hline${ }^{3} \mathrm{He} /{ }^{4} \mathrm{He}\left(10^{6}\right)$ & 1.4 & 1.49 \\
\hline
\end{tabular}

Table 2 Isotopic composition of GSJ borehole water sampled in 1996 April and 2000 February. Data of the1996 water is after Sato and Takahashi (2000). 

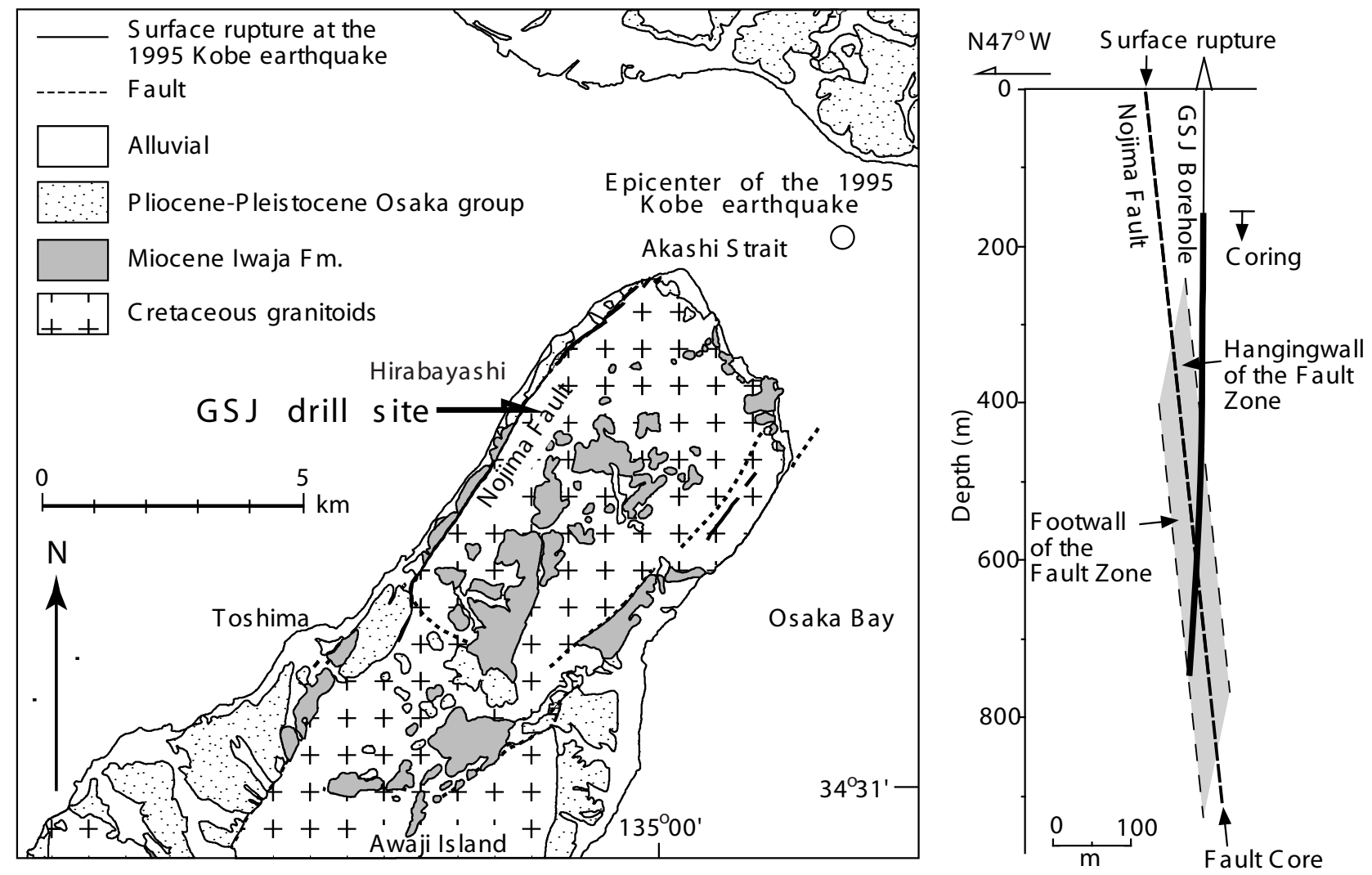


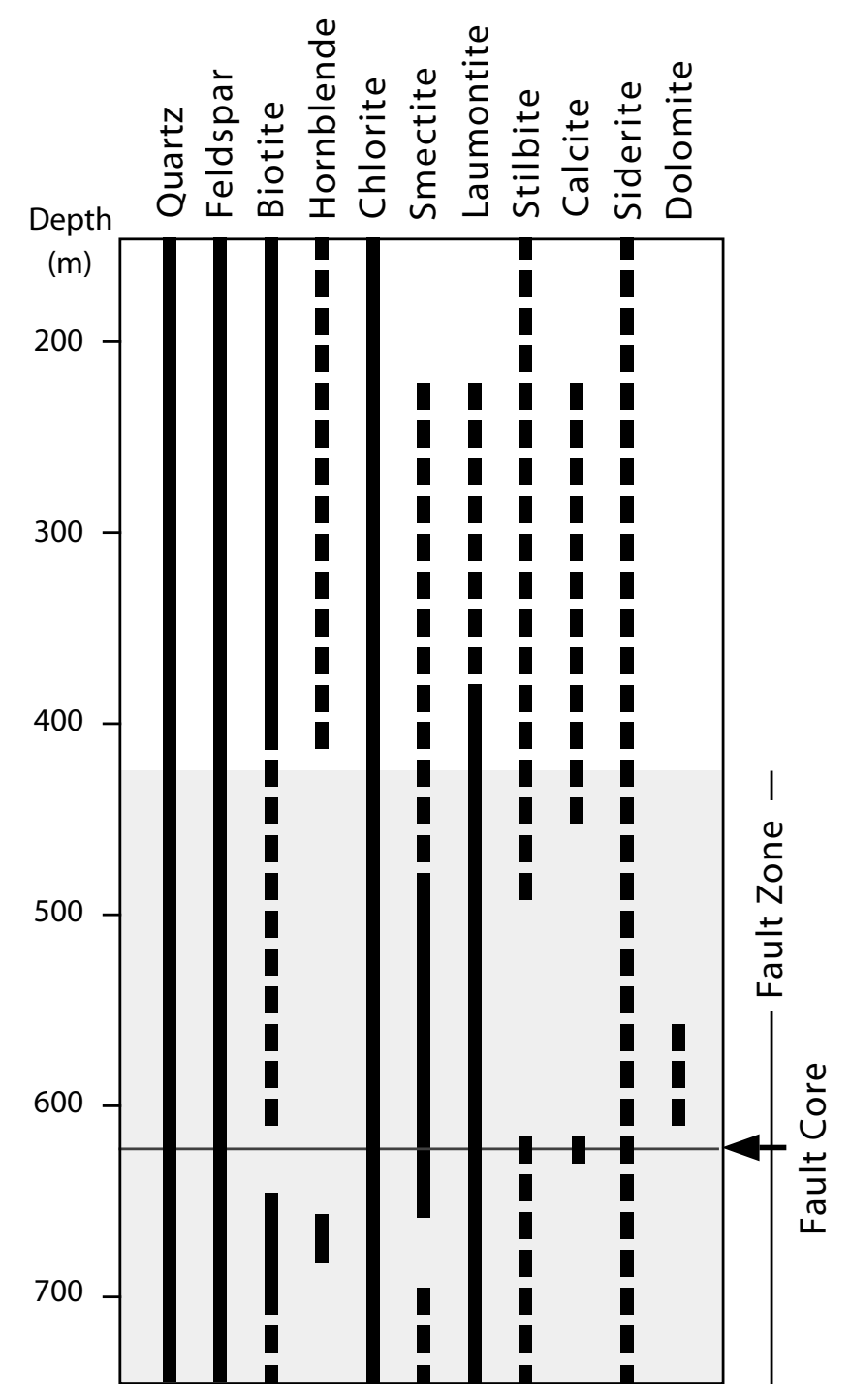




\section{a. 1996 water}

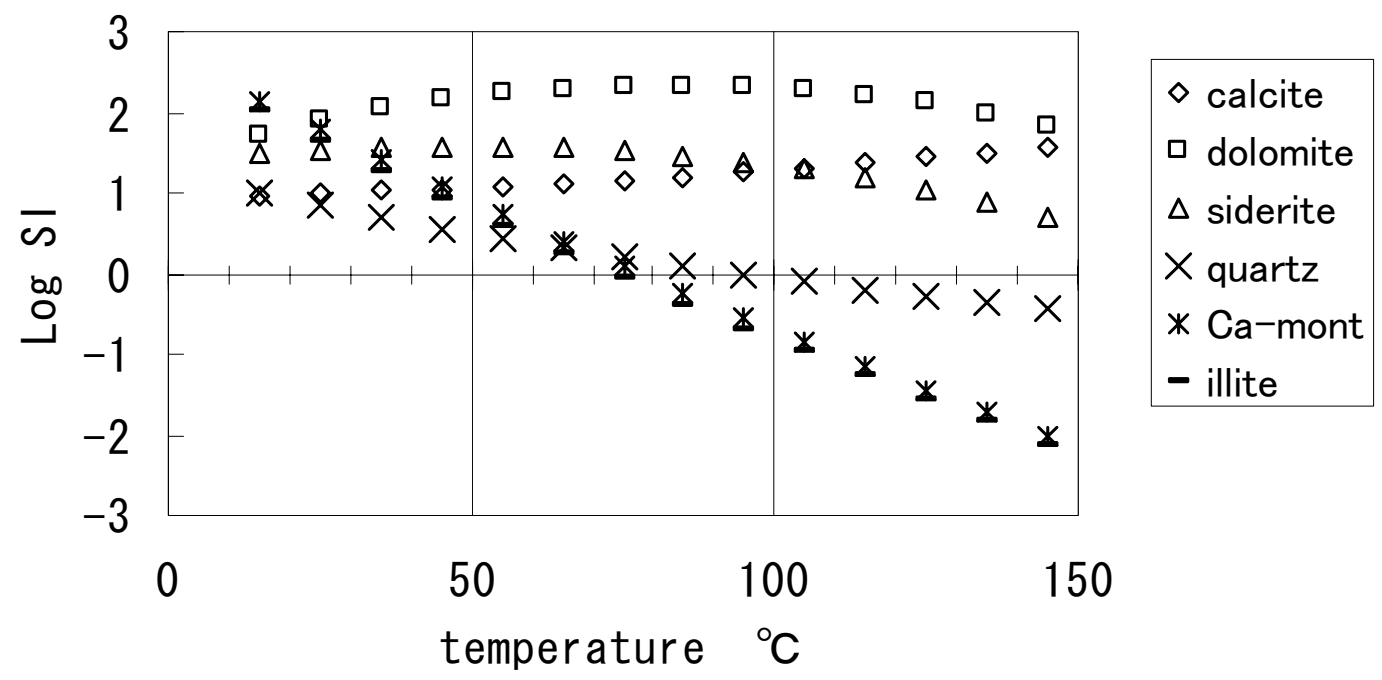

\section{b. 2000 water}

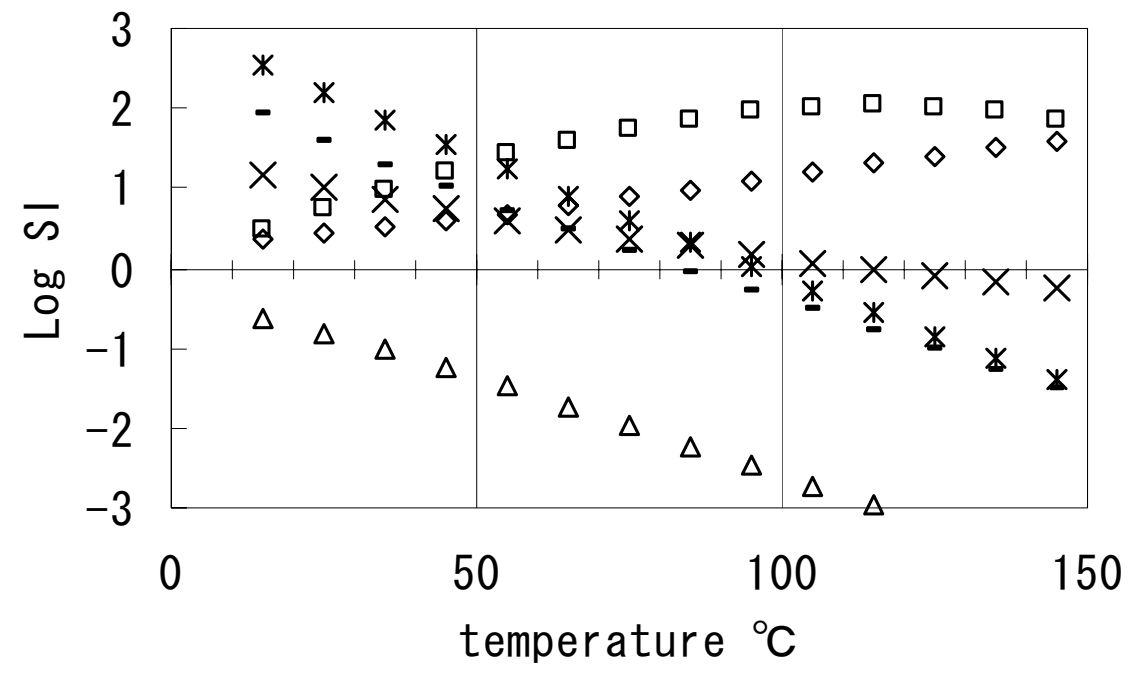




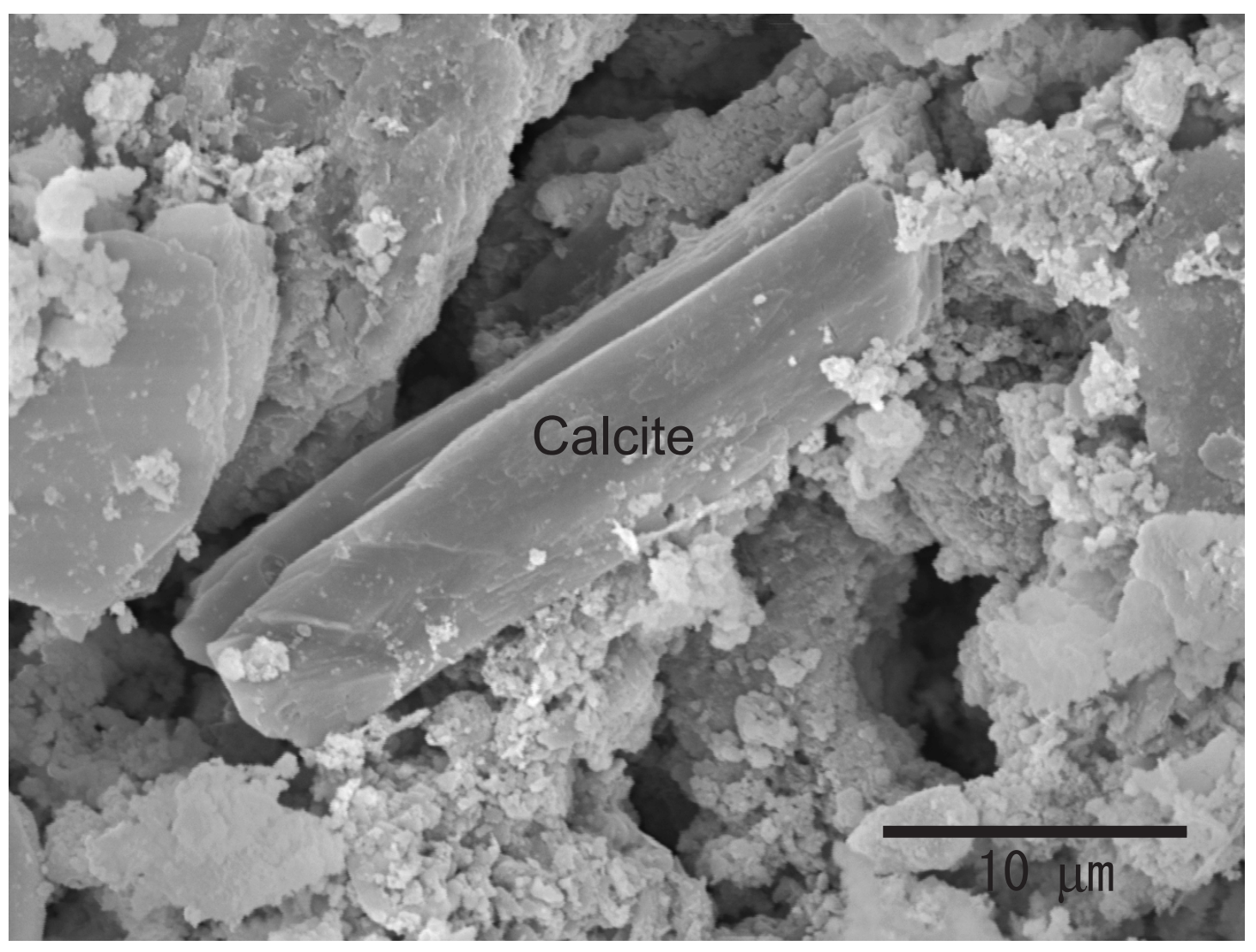




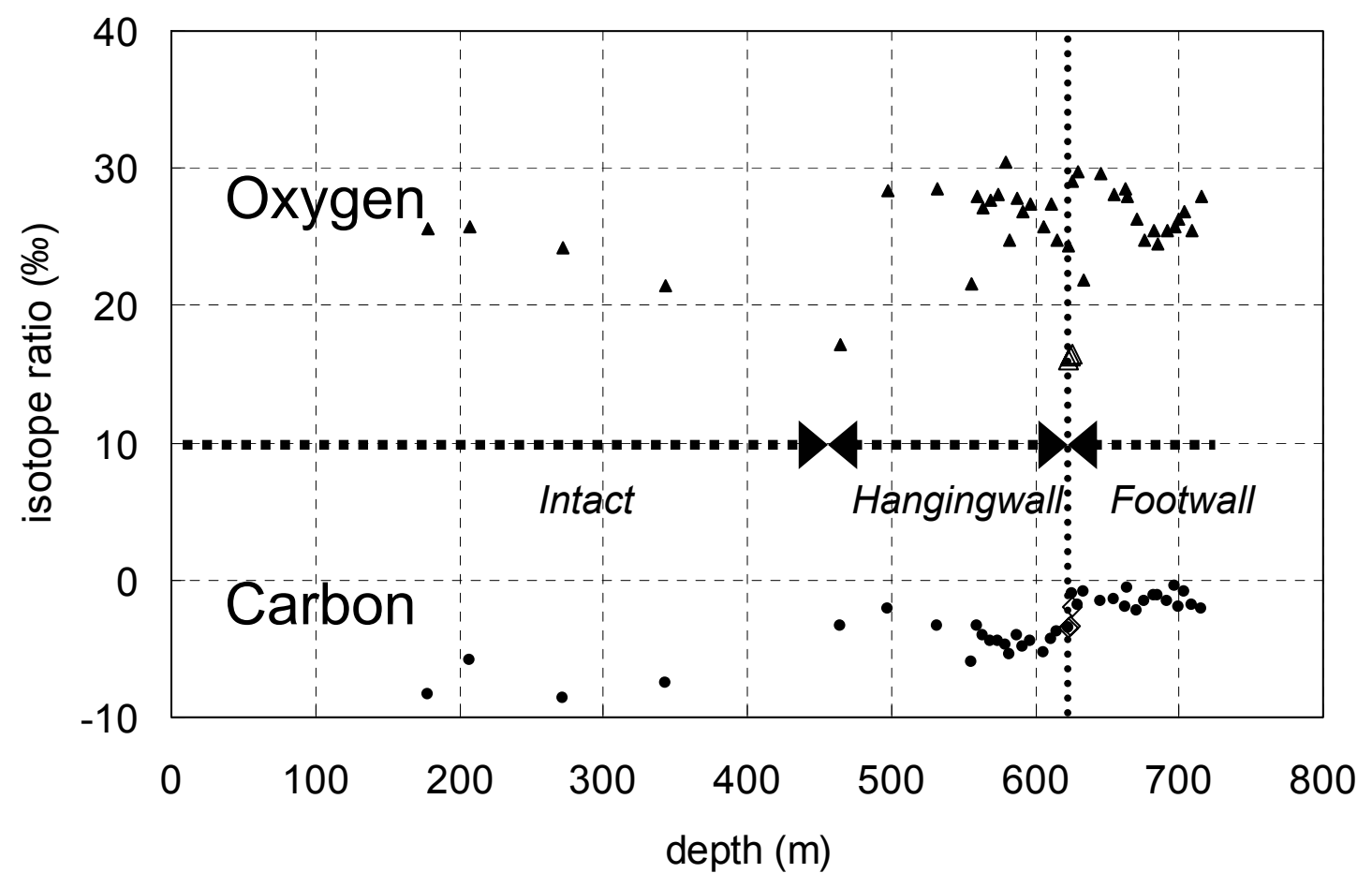




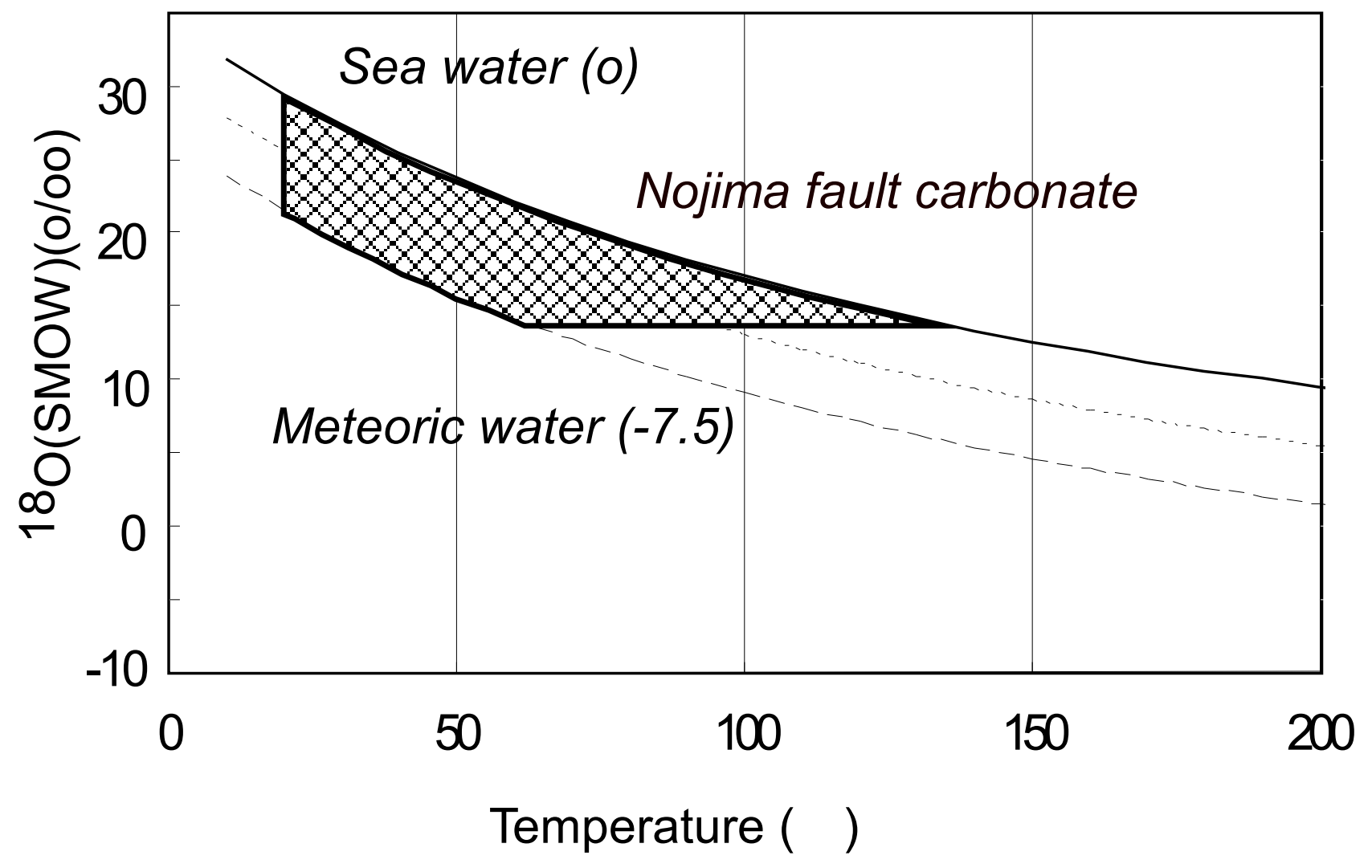

